\title{
The record 2013 Southern Hemisphere sea-ice extent maximum
}

\author{
Phil REID, ${ }^{1}$ Sharon STAMMERJOHN, ${ }^{2}$ Rob MASSOM, ${ }^{3}$ Ted SCAMBOS,${ }^{4}$ Jan LIESER ${ }^{5}$
}

\author{
${ }^{1}$ Bureau of Meteorology, Centre for Australian Weather and Climate Research and Antarctic Climate and Ecosystems CRC, \\ Hobart, Tasmania, Australia \\ E-mail: p.reid@bom.gov.au \\ ${ }^{2}$ Institute of Arctic and Alpine Research, University of Colorado at Boulder, Boulder, CO, USA \\ ${ }^{3}$ Australian Antarctic Division and Antarctic Climate and Ecosystems CRC, Hobart, Tasmania, Australia \\ ${ }^{4}$ National Snow and Ice Data Center, University of Colorado at Boulder, Boulder, CO, USA \\ ${ }^{5}$ Antarctic Climate and Ecosystems CRC, Hobart, Tasmania, Australia
}

\begin{abstract}
Observations of Southern Hemisphere sea ice from passive microwave satellite measurements show that a new record maximum extent of $19.58 \times 10^{6} \mathrm{~km}^{2}$ was reached on 30 September 2013; the extent is just over two standard deviations above the 1979-2012 mean and follows a similar record $\left(19.48 \times 10^{6} \mathrm{~km}^{2}\right)$ in 2012 . On the record day in 2013, sea-ice extent was greater than the 30 year average (1981-2010) in nearly all Southern Ocean regions. For the year as a whole, Southern Hemisphere sea-ice area and extent were well above average, and numerous monthly and daily records were broken. Analysis of anomaly patterns and the atmospheric and oceanic events suggests that a sequence of regional wind and cold-freshened surface waters is likely responsible for the record maximum and the generally high 2013 extent. In particular, the Ross Sea sector experienced a combination of cold southerly winds associated with the position and depth of the Amundsen Sea low, and lower than normal sea surface temperatures (up to $2^{\circ} \mathrm{C}$ below normal). The resulting very high anomaly in ice extent in this region was a major component of the overall record maximum.
\end{abstract}

KEYWORDS: atmosphere/ice/ocean interactions, climate change, sea ice

\section{INTRODUCTION}

While Arctic sea ice is in spiralling decline (Stroeve and others, 2012), the annual maximum extent of Southern Hemisphere $(\mathrm{SH})$ sea ice has increased by $1 \%$ per decade (significant to the 99\% level) since 1979, the year when a continuous record of multifrequency passive microwave satellite observations began (Watkins and Simmonds, 2000; Comiso and Nishio, 2008; Turner and others, 2009; Comiso, 2010; Parkinson and Cavalieri, 2012). The greatest SH ice extent maximum observed to date occurred in 2013, when numerous other records were also set (Table 1). Monthly extent trends for 1979-2013 are positive throughout the year at rates ranging from $0.8 \%$ (August and November) to $3.9 \%$ (February), with all except January having a significance level of $>95 \%$. High variability dominates the trend for the austral summer and autumn months (December-April), but statistically significant trends are present for the remainder of the year. The 2013 event is perhaps most remarkable because sea-ice extent was well above the long-term average or at a record for the entire year. A key question revolves around why, in an era of marked global warming, new records of maximum extent continue to be set for net $\mathrm{SH}$ sea ice. The 2013 event may provide some answers to help us understand why this is occurring.

Large-scale atmospheric patterns associated with the El Niño Southern Oscillation (ENSO), Southern Annular Mode (SAM) and ozone depletion significantly influence $\mathrm{SH}$ seaice extent (Harangozo, 2006; Holland and Kwok, 2012), concentration (Liu and others, 2004; Simpkins and others, 2012), volume (Zhang, 2014) and seasonality (Stammerjohn and others, 2008, 2012; Massom and Stammerjohn, 2010; Massom and others, 2013a). The atmospheric patterns associated with these climate modes impact regional sea ice in variable ways. For example, under positive SAM and neutral ENSO conditions (resulting in strengthened $\mathrm{SH}$ westerlies), there is a tendency for sea ice to advance earlier in the western Ross Sea sector but later in the Bellingshausen Sea sector (Stammerjohn and others, 2008, fig. 7d; Turner and others, 2009; Simpkins and others, 2012).

The trend in autumn sea-ice extent over the last $>30$ years has been linked to springtime ozone depletion (Turner and others, 2009) and decadal changes in the mean state of the SAM (Stammerjohn and others, 2008), while changes in springtime sea-ice (maximum) extent have occurred in association with the high-latitude atmospheric response to various phases and interactions of ENSO and the SAM (Stammerjohn and others, 2008; Yuan and Li, 2008; Schneider and others, 2012; Simpkins and others, 2012). However, model-based studies (Sigmond and Fyfe, 2010, 2014) show that ozone depletion is accompanied by a decrease in sea-ice extent throughout the year, and that the recently observed positive trends in sea-ice extent are likely a result of large internal variability (Sigmond and Fyfe, 2014).

Within the overall 34 year trend of weak hemisphericwide sea-ice increase, contrasting regional trends of larger magnitude have occurred. Most notable are a significant decline in the western Antarctic Peninsula-Bellingshausen Sea (WAP-BS) region and an increasing ice extent trend in the western Ross Sea (WRS) (Comiso and Nishio, 2008; Parkinson and Cavalieri, 2012). While sea ice is advancing later (by $61 \pm 16$ days) and retreating earlier (by $38 \pm 13$ days) in the WAP-BS region (total change over 1979-2010), the opposite is occurring in the WRS region (i.e. advance is $42 \pm 10$ days earlier and retreat $38 \pm 10$ days later; Stammerjohn and others, 2012). This translates to a decrease of $99 \pm 32$ ice-season days in the WAP-BS and an increase of $80 \pm 13$ ice-season days in the WRS. Cohen and others (2013) and Coggins and others (2014) show that 
Table 1. Statistics for the 2013 Southern Hemisphere sea-ice season

\begin{tabular}{lc} 
Record description & Value \\
\hline New daily record for sea-ice extent & $19.58 \times 10^{6} \mathrm{~km}^{2}$ \\
Previous daily record for sea-ice extent & $19.48 \times 10^{6} \mathrm{~km}^{2}$ \\
New record for monthly average sea-ice extent & $19.79 \times 10^{6} \mathrm{~km}^{2}$ \\
Previous greatest monthly average sea-ice extent & $19.41 \times 10^{6} \mathrm{~km}^{2}$ \\
Greatest daily recorded sea-ice area during 2013 & $15.68 \times 10^{6} \mathrm{~km}^{2}$
\end{tabular}

Number of days in 2013 above the previous (2012) daily record

New monthly sea-ice extent records achieved in 2013

New monthly sea-ice areas recorded in 2013

Number of days of record sea-ice extent in 2013 Number of days of record sea-ice area in 2013
14 days

August $\left(18.93 \times 10^{6} \mathrm{~km}^{2}\right)$, September $\left(19.79 \times 10^{6} \mathrm{~km}^{2}\right)$, October $\left(19.39 \times 10^{6} \mathrm{~km}^{2}\right)$, November $\left(17.12 \times 10^{6} \mathrm{~km}^{2}\right)$ August $\left(15.03 \times 10^{6} \mathrm{~km}^{2}\right)$, October $\left(14.95 \times 10^{6} \mathrm{~km}^{2}\right)$, November $\left(12.57 \times 10^{6} \mathrm{~km}^{2}\right)$ 108 days 114 days the positioning of low-pressure systems in the Ross Sea sector is related to ENSO and SAM patterns and thereby influences the local climate parameters in this region. These regional sea-ice trends have important physical and biological consequences (Massom and Stammerjohn, 2010).

While changes in atmospheric dynamics impact regional sea-ice extent (Holland and Kwok, 2012), other research suggests that changes in sea surface temperatures (SSTs) and upper-ocean freshening may also be playing an important role in sea-ice trends (e.g. Goosse and others, 2009; Liu and Curry, 2010; Bintanja and others, 2013; Li and others, 2014). Overall, April-September SST south of $50^{\circ} \mathrm{S}$ has decreased over the last few decades (Bintanja and others, 2013), although there are notable regional exceptions, including the Bellingshausen Sea. Upper-ocean freshening, which acts to enhance sea-ice growth by stabilizing the upper ocean and insulating it from deep ocean heat, has been attributed to an increase in precipitation entering the Southern Ocean (Liu and Curry, 2010) and increased basal ice-shelf melt (Hellmer and others, 2012; Pritchard and others, 2012; Rignot and others, 2013). Together these studies suggest that freshwater inputs to the Southern Ocean are not well represented in climate models, which may explain why global coupled models currently fail to simulate observed sea-ice increases (e.g. Liu and Curry, 2010; Bintanja and others, 2013).

For our examination of the 2013 event, it is also important to understand the mechanisms involved in large-scale sea-ice seasonality (advance and retreat) and how they may vary regionally. Broadly speaking, Antarctic sea-ice advance and retreat involves a mix of thermodynamic and dynamic (advective) processes. The mix of these processes is not, however, regionally or temporally consistent (Kimura and Wakatsuchi, 2011). For example, the Ross Sea experiences rapid and early growth and contributes ice to neighbouring regions through zonal advection at different times of the year: coastal (circumpolar) currents appear to be responsible for early (late) zonal flow to the west (east) from the Ross Sea (Kimura and Wakatsuchi, 2011). The positioning and depth of the Amundsen Sea low (ASL) is also vital in determining the sea-ice extent and seasonality in this region, and is linked with large-scale atmospheric/oceanic patterns (Stammerjohn and others, 2008; Hosking and others, 2013; Turner and others, 2013a). The Weddell Sea, on the other hand, has a later peak ice production than that in the Ross Sea and contributes, through zonal advection, to the ice budget within the adjoining Haakon VII Sea to the east (fig. 9 of Kimura and Wakatsuchi, 2011).

Below we examine the winter maximum sea-ice extent record of 2013 within the context of large-scale interactions between sea ice, ocean and atmosphere during the months both preceding and following the event. In so doing, we propose some reasons for the unusual sea-ice-climate event observed in the Ross Sea sector in particular.

\section{RESULTS}

\section{Overview}

Table 1 includes statistics for the 2013 event and the 2013 winter sea-ice season. On a daily basis, total sea-ice extent and area were above average for the entire year (Fig. 1a and b), with many days setting new record high extents for those dates. For much of the latter part of the year, daily values of net sea-ice coverage were over two standard deviations above the mean. Indeed the new daily record of $19.58 \times 10^{6} \mathrm{~km}^{2}$ (30 September 2013, based on Cavalieri and others, 1996, updated 2013) is just over two standard deviations above the mean annual daily maxima for 19792012. This follows a similar daily record $\left(19.48 \times 10^{6} \mathrm{~km}^{2}\right)$ set in 2012 (Massom and others, 2013a; Reid and others, 2013; Turner and others, 2013b).

Differences between the time series of extent and area are illuminating. Sea-ice extent (Fig. 1a) increased quickly from close to the climatological mean in early January to setting new daily records in early February, whereas sea-ice area (Fig. 1b) was well above average or at record levels from the beginning of the year. For February through November, seaice extent remained between 0.7 and $1.0 \times 10^{6} \mathrm{~km}^{2}( \pm 0.15$ $\times 10^{6} \mathrm{~km}^{2}$ variation) above the long-term mean. Over the same period, sea-ice area anomaly varied between 0.3 and $1.3 \times 10^{6} \mathrm{~km}^{2}\left( \pm 0.5 \times 10^{6} \mathrm{~km}^{2}\right.$ variation). This larger range 
in area is due to variability in ice concentrations inside the $15 \%$ concentration ice edge (impacting on area not extent), likely resulting from enhanced thermodynamic growth during periods of wind- or ocean-driven divergence within the pack ice. This growth in area occurred predominantly between 2 and 16 June, followed by a reduction in sea-ice area from 18 to 22 June. The latter was caused by intense cyclonic activity and pack-ice convergence. A second period of increase in sea-ice area occurred from early to mid-July.

As revealed by Figure $1 \mathrm{a}$ and $\mathrm{b}$, the record-breaking events of 2013 were the result of early and steady growth throughout the year. Thus, the 2012 and 2013 maximum sea-ice events transpired under quite different circumstances. As shown by Turner and others (2013b), the 2012 event was strongly moderated by large-scale synoptic systems, which caused rapid ice expansion in mid- to late September that resulted in (at the time) a record-breaking winter ice maximum.

Sea-ice retreat during austral spring/summer 2012/13

Southern Hemisphere sea-ice retreat in 2012/13 is described by Massom and others (2013b) and shown here in Figure 2a. In general, the positioning of the ASL further west than usual at $\sim 160^{\circ} \mathrm{W}$ (see fig. $6.3 \mathrm{~g}$ of Fogt and Scambos, 2013) coincided with an early retreat over the outer pack of the Amundsen Sea and a late sea-ice retreat in the outer pack ice of the Bellingshausen Sea/western Weddell Sea sector. There was late retreat across much of the far east of the Antarctic $\left(\sim 100-175^{\circ} \mathrm{E}\right)$ and Haakon VII Sea $\left(\sim 10^{\circ} \mathrm{W}-10^{\circ} \mathrm{E}\right)$ and early retreat of the outer pack ice in the eastern Weddell Sea $\left(\sim 0-30^{\circ} \mathrm{E}\right)$ and Indian Ocean $\left(\sim 85-100^{\circ} \mathrm{E}\right)$. During the retreat phase, the predominant $\mathrm{SH}$ synoptic pattern had relatively high pressure over the continent and Bellingshausen-Amundsen Sea (BAS) sector, and low-pressure areas in the mid-latitudes. Overall, circulation was similar to a zonal three-wave pattern (Wovrosh and others, 2013).

\section{Sea-ice advance during the austral autumn/winter 2013}

There are considerable regional differences in the timing of sea-ice advance in 2013 compared with the long-term average (Fig. 2b). Much of the inner Weddell Sea and East Antarctica through to the western Ross Sea $\left(\sim 90^{\circ} \mathrm{E}-160^{\circ} \mathrm{W}\right)$ showed early advance, predominantly as a result of late or incomplete sea-ice retreat in those regions. The inner WAPBS and small parts of East Antarctica (to the north of the Amery Ice Shelf) showed later advance. These anomalies are fairly consistent with long-term trends in sea-ice advance (Stammerjohn and others, 2008, 2012; Massom and Stammerjohn 2010; Massom and others, 2013b). However, there are some notable anomalies in the 2013 sea-ice advance season. In particular, there was a late-season surge in ice-edge advance/growth in the outer pack from the western Ross Sea to WAP-BAS region, which is uncharacteristic of the trend in these outer regions. In contrast, seaice advance in the outer pack of the west-central Weddell Sea was considerably later than usual. A further contrast in trend is the early advance in East Antarctica $\left(90-140^{\circ} \mathrm{E}\right.$; Fig. 1d) (Massom and others, 2013b).

\section{Large-scale synoptic conditions associated with 2013 sea-ice advance}

We can gather information about the progress of, and impacts on, the 2013 sea-ice season by examining monthly

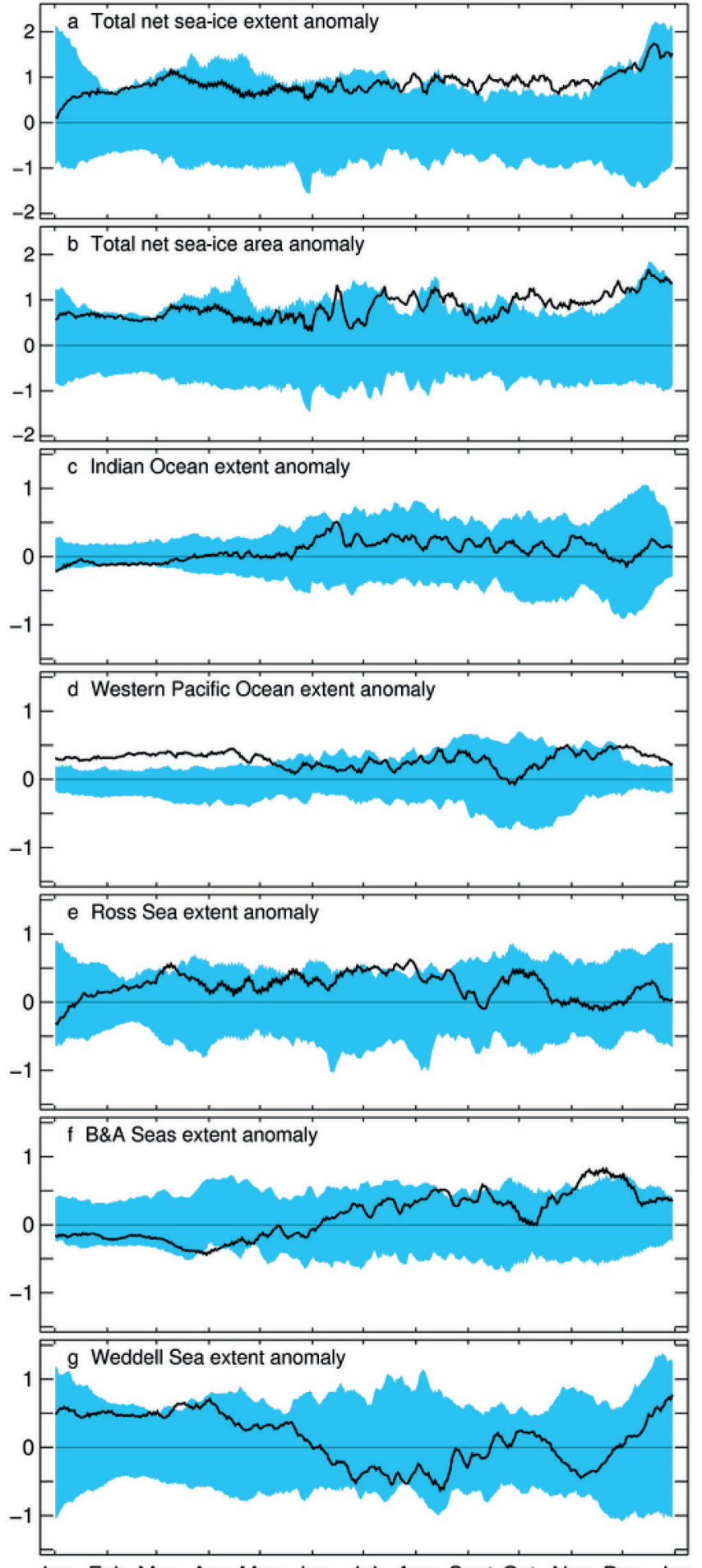

Jan Feb Mar Apr May Jun Jul Aug Sept Oct Nov Dec Jan

Fig. 1. Plots of daily anomalies (black lines) from climatology (1981-2010) of total Southern Hemisphere sea-ice (a) extent and (b) area and (c-g) extent for the Indian Ocean (c), western Pacific Ocean (d), Ross Sea (e), Bellingshausen and Amundsen Seas ( $f$ ) and Weddell Sea (g) for 2013. Regions are based on the standard NASA regions (Zwally and others, 1983). Blue banding represents the range of daily values for 1981-2010.

maps of sea-ice concentration in conjunction with SST anomalies (SSTa), broadscale atmospheric pressure patterns (shown as $850 \mathrm{hPa}$ geopotential height anomalies) and lowlevel atmospheric temperature patterns (shown as $925 \mathrm{hPa}$ temperature anomaly patterns) (Fig. 3a-l). Note that Figure 3 also shows the ice-edge climatology (black contour) to 
a

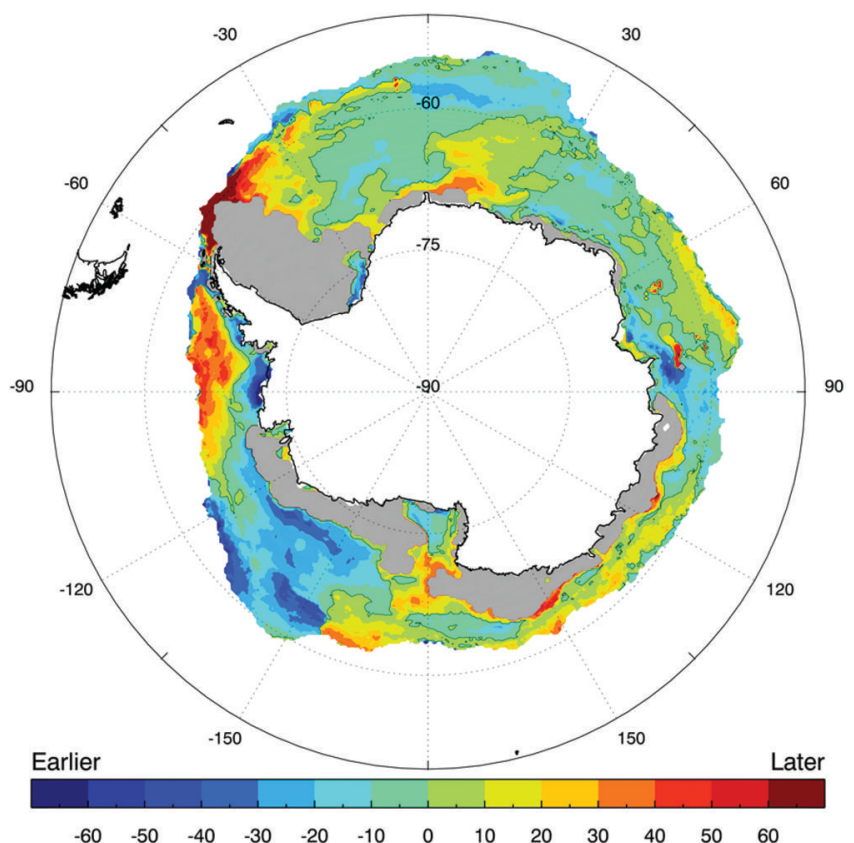

b

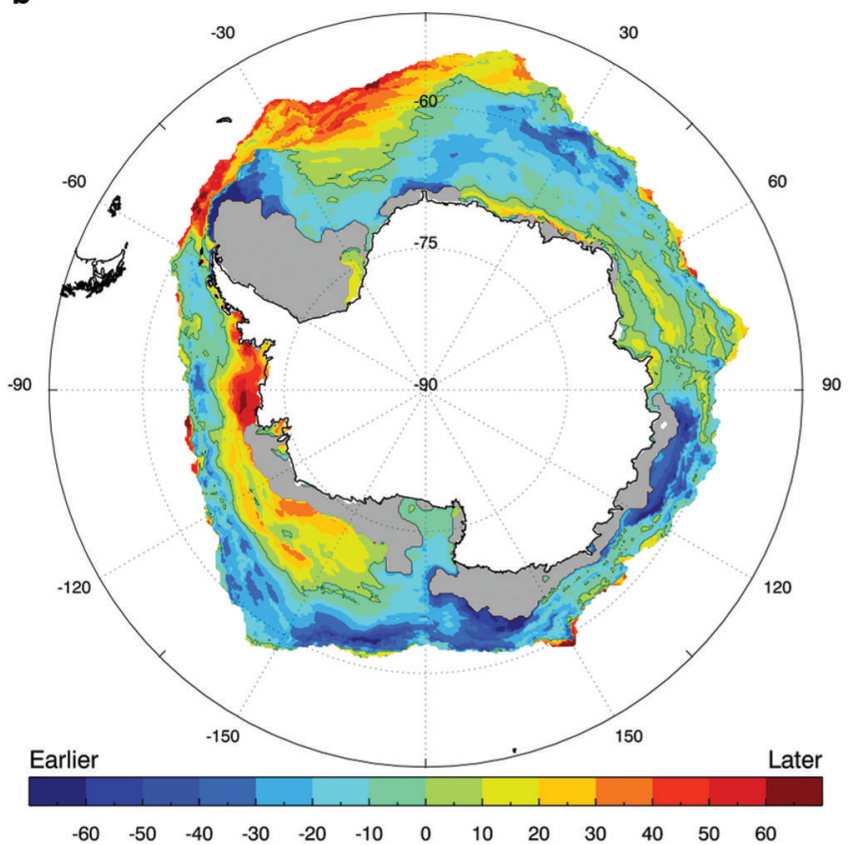

Fig. 2. Anomaly maps of the timings in days of (a) sea-ice retreat in 2012/13 and (b) advance in 2013. Regions where sea ice did not fully retreat are shown in light grey.

identify regions of above/below mean sea-ice extents. Atmospheric and oceanic indicators in the equatorial Pacific suggest that ENSO remained neutral from mid-2012 to the end of 2013 (Fogt and others, 2013). However, in early 2013 there was a deepening of the Antarctic Circumpolar Trough and relatively low atmospheric pressure across the continent, along with higher than normal pressure through the mid-latitudes, consistent with the positive SAM pressure pattern that occurred for much of January-July (see respective $850 \mathrm{hPa}$ geopotential height anomalies; Fig. 3a-g). The synoptic pattern associated with positive SAM provided a poleward movement of low-pressure systems and general strengthening of the westerly winds around Antarctica. Thus, conditions were conducive for a wind-driven sea-ice-edge advance (e.g. Watkins and Simmonds, 1999; Holland and Kwok, 2012) to augment thermally driven ice-edge growth.

In mid-August there was a change from positive to negative SAM as a high air-pressure anomaly covered continental Antarctica and lower than normal pressures were present in the mid-latitudes (Fig. 3h). This reduced the strength of the westerly winds and displaced them to lower latitudes, a pattern that persisted through to October. This distinct change in pressure pattern was a key part of the conditions that led to the record maximum. With this decreased westerly pattern, wind-driven sea-ice-edge expansion decreased in mid-August as westerly winds subsided, but a predominantly thermally driven increase in seaice concentrations occurred during August through October. This is consistent with the observation of an increase in seaice area anomaly (Fig. 1b) from September onwards due to increased concentrations inside the ice edge. The sea-ice extent anomaly remained high but relatively constant during this period.

In November there was again a switch in atmospheric pressure patterns (Fig. 3k), with a trough developing over West Antarctica and a high-pressure ridge just off the continent extending from Dronning Maud Land and much of East Antarctica. This entailed a positive SAM for November and December 2013.

\section{Regional response: the Bellingshausen, Amundsen and Ross Sea sector}

As mentioned earlier, sea ice was extensive in the Ross Sea during 2013, breaking daily records in March and July (Fig. 1e). North and west of the Ross Sea $\left(150-180^{\circ} \mathrm{E}\right)$, sea ice did not retreat fully to its climatological mean minimum extent during summer 2012/13 (January-February; Fig. 3a and b). During this time, lower than normal SSTs just to the north of the ice edge and stronger westerly winds in this region, particularly during February 2013 when the ASL was in the Ross Sea (Fig. 3b), may have contributed to the greater remaining ice cover in this region. In contrast, to the east of the Ross Sea, ice retreated fully in the Bellingshausen Sea, and sea-ice extent was lower than its climatological norm in the Amundsen Sea (Fig. 1f), the latter being consistent with higher than normal SSTs just to the north of the ice edge there, along with a northerly atmospheric flow (Fig. 3b).

In the Ross Sea, sea-ice growth during the early advance period March-May 2013 (Fig. 3c-e) was dominated by strong westerly winds and lower than normal SSTs to the north of the sea-ice edge. The increased depth and eastward expansion of the ASL led to stronger than normal westerly winds $\left(2-3 \mathrm{~m} \mathrm{~s}^{-1}\right.$ stronger at the surface averaged over the 3 months; not shown) and thus stronger Ekman sea-ice drift. Further east, a large negative sea-ice extent anomaly dominated the BAS region, associated with relatively warmer northerly winds along the eastern limb of the expanded ASL.

In June (Fig. 3f), there was a continued northward expansion of the cold pool of surface water north of the Ross Sea, which expanded/propagated eastwards as it interacted with the surface winds and Antarctic Circumpolar Current. The ASL migrated east and provided cool southerly winds over the BAS, enhancing the sea-ice extent in this region. In July (Fig. 3g), the cold surface waters enveloped the ice edge to the north of the BAS region and, combined with cooler atmospheric conditions, enhanced sea-ice growth in this region. As a result, a marked enhancement 


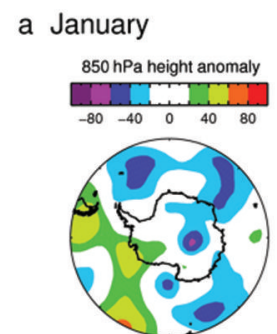

b February

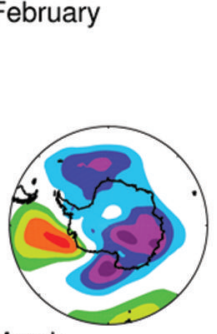

c March
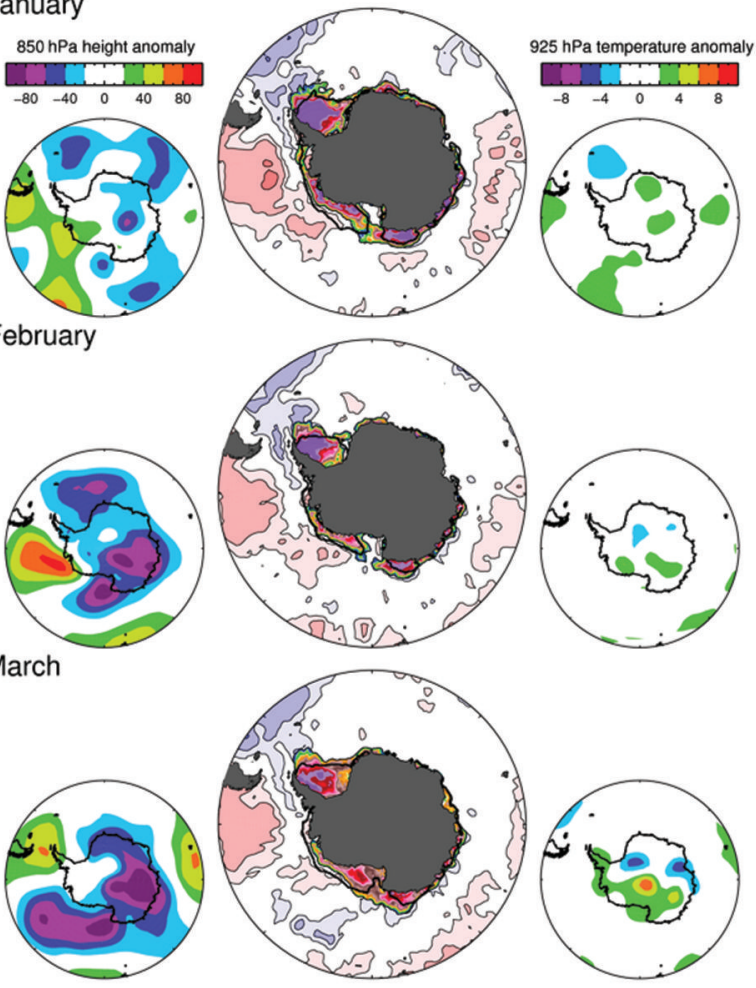

d April
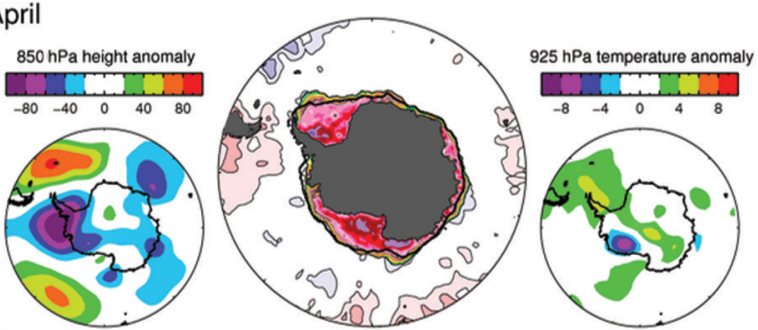

e May
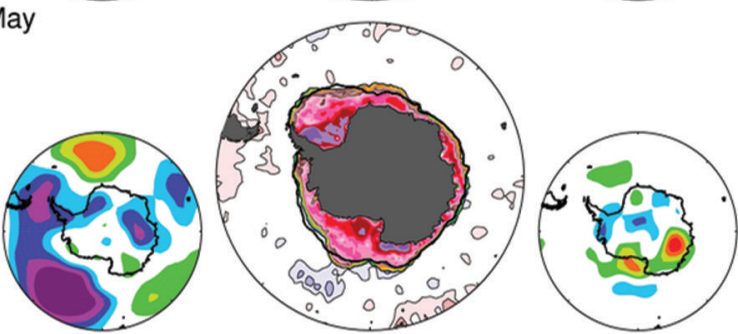

f June
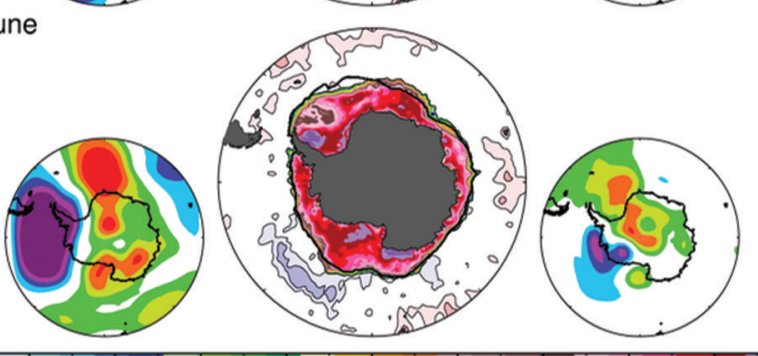

g July

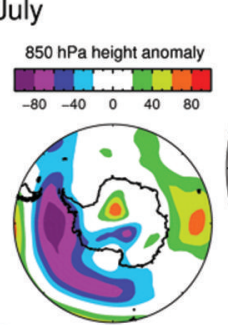

h August

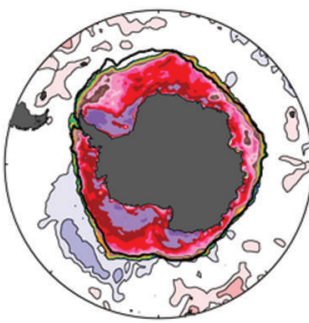

$925 \mathrm{hPa}$ temperature anomal
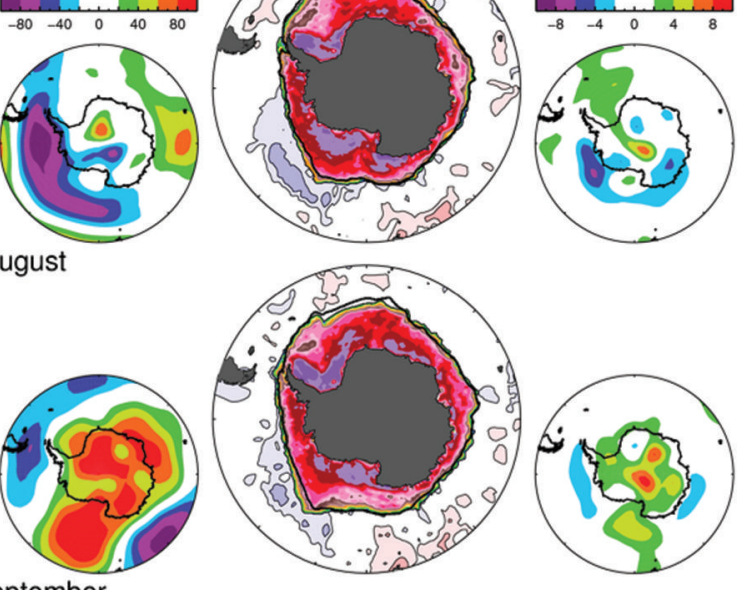

i September
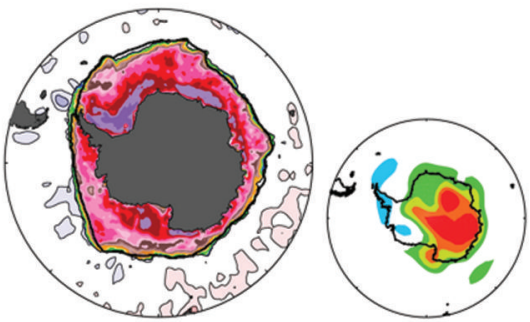

j October
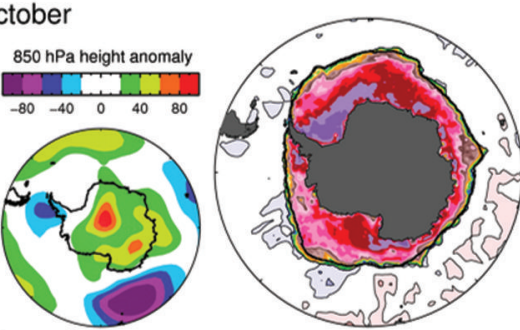

\begin{tabular}{|lllllll}
\hline $925 \mathrm{hPa}$ & & & \\
\hline
\end{tabular}

k November
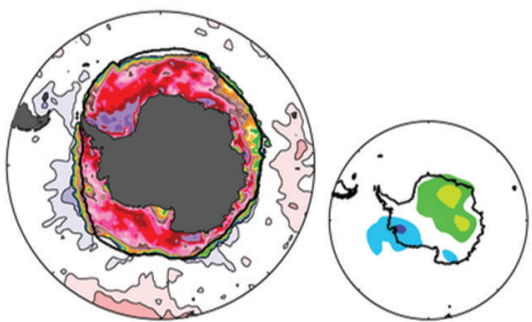

I December
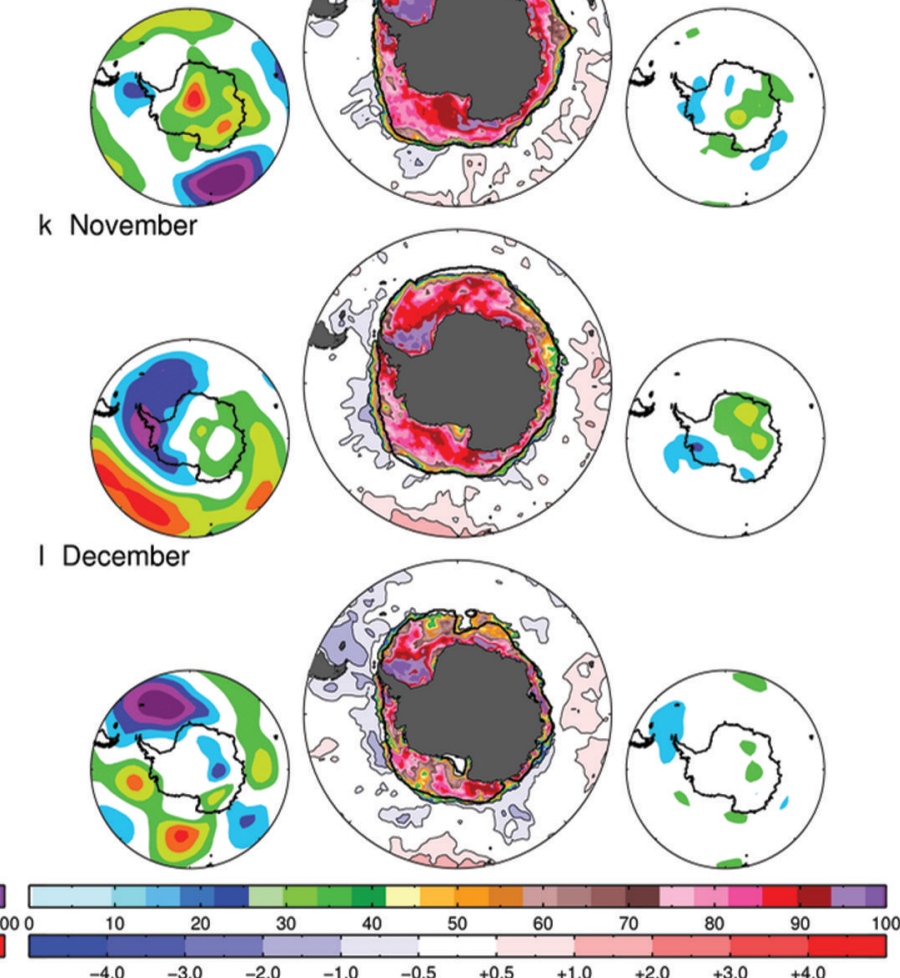

Fig. 3. Maps of monthly mean sea-ice concentration (\%; top key) and monthly mean SST anomalies $\left({ }^{\circ} \mathrm{C}\right.$; bottom key) for (a-I) JanuaryDecember 2013. Sea-ice-edge climatology (1981-2010) is shown as a bold black line. Left column is the respective 850 hPa geopotential height anomaly; right column is the respective $925 \mathrm{hPa}$ temperature anomaly. All anomalies are with respect to $1981-2010$.

of sea-ice extent occurred across the region in July, stretching from the Ross Sea eastward to the Bellingshausen Sea $\left(180-85^{\circ} \mathrm{W}\right)$.

The strength of the westerly winds decreased during August in this sector, but the pattern of cold SSTs persisted in this and subsequent months of 2013 (Fig. 3h-l). This, along with the shift of the ASL to the Bellingshausen Sea in November, allowed further expansion of the sea-ice edge in the BAS region during early November, before it began its retreat in late November. 


\section{Regional response: the Weddell Sea}

In late austral summer 2013 (January-February), sea-ice concentration in the Weddell Sea showed some deviation from its climatological values and recent trends (Fig. 3a and b). In these months, sea-ice concentrations close to the coast were much lower than normal. At the same time, however, the sea-ice edge to the north did not retreat much beyond $60^{\circ} \mathrm{S}$, enhanced by strong westerly winds crossing to the north of the Antarctic Peninsula and driving northward Ekman drift of the ice. Northerly drift of the ice combined with lower than normal SSTs to the north of the ice edge provided conditions favouring minimal retreat and enhanced sea-ice extent (Fig. 1g).

In March (Fig. 3c), the ASL moved eastwards and closer to the Bellingshausen Sea, leading to northerly winds over the Weddell Sea; this resulted in a slight decrease in ice concentration east of the Antarctic Peninsula. In April (Fig. 3d), the cold pool of surface waters in the Weddell Sea sector dissipated, and ice-edge advance (Fig. 2b) slowed from April to July, resulting in predominantly lower than average sea-ice extent for much of June-November (Fig. 1g).

\section{Regional response: East Antarctica}

In comparison, mixed regional and relatively small-scale sea-ice responses in concentration and seasonality occurred across East Antarctica in 2013. The position of low-pressure regional anomalies was responsible for much of the sea-ice variability, although lower than normal SSTs were observed to the north of the ice edge east of $\sim 90^{\circ} \mathrm{E}$ and west of $\sim 175^{\circ} \mathrm{E}$ during the austral summer and autumn (Fig. 3a-f). Pockets of sea ice, mostly to the east of $90^{\circ} \mathrm{E}$, did not fully retreat during austral summer 2012/13 (Fig. 2a). Autumn advance occurred earlier than usual in these regions, predominantly consistent with long-term trends (Massom and others, 2013b), and sea-ice extent during this period was well above average (Fig. 1d). Further to the west, relatively warm northerly winds associated with the positioning of a low-pressure trough off Dronning Maud Land during January-April (Fig. 3a-d) were responsible for a late advance of the sea-ice edge and low sea-ice extent in that area (Fig. 1c). During May and June (Fig. 3e and f) the low-pressure trough moved further east to provide cooler southerly winds for a late advance of the ice edge west of $\sim 90^{\circ} \mathrm{E}$ (Figure $2 \mathrm{~b}$ ).

During August (Fig. 3h), atmospheric pressure built up over the continent, and the low-pressure trough was located further north, particularly in the East Antarctic sector. As a result, from August to October (Fig. 3h-j) wind-driven seaice-edge advance was reduced. Subsequently, sea-ice extent remained close to, or slightly above, its climatological mean for the rest of the year (Fig. 1c and d). Notable exceptions to this include Prydz Bay (55-90 $\left.{ }^{\circ} \mathrm{E}\right)$ and Commonwealth Bay $\left(130-150^{\circ} \mathrm{E}\right)$, regions where sea-ice concentrations remained relatively high during the 2013 retreat (November and December; Fig. $3 \mathrm{k}$ and I) due to low levels of transient cyclonic activity in these regions. In late December 2013, heavy sea-ice conditions in Commonwealth Bay, in part due to the absence of Mertz Glacier tongue, which calved and drifted away in 2010 (Tamura and others, 2012), were responsible for trapping the Russian research vessel Akademik Shokalskiy (Turney, 2014).

\section{DISCUSSION}

It would appear that a number of complex and closely coupled interactive mechanisms were involved in driving the record-breaking maximum sea-ice extent of 2013. First, in the preceding 2012/13 spring and summer, sea ice did not fully retreat in a number of regions around the Antarctic coastline. These same regions also experienced early and extensive sea-ice growth in the following autumn and, particularly in the Ross Sea sector, expanded to neighbouring regions during the following months. Several studies have suggested that there is a relationship between the variability of sea-ice retreat and advance in the subsequent year (Nihashi and Ohshima, 2001; Stammerjohn and others, 2008, 2012), and this appears to be the case in 2013.

Second, relatively strong westerly winds and the positioning of low-pressure regions (notably the ASL) in the West Antarctic sector were certainly influential in the expansion of sea ice in these regions in 2013. However, sea ice in this region also appears to have advanced in response to, and in tandem with, an expanding pool of relatively cold surface water. The origins of this cold pool are unclear but may be related to increased freshwater inputs along the West Antarctic coastline (e.g. Jacobs and Giulivi, 2010) resulting from increased basal ice-shelf melt and iceberg calving (Rignot and others, 2013) and/or increased precipitation (Liu and Curry, 2010). As the westerly winds weakened in late August (and the SAM index turned negative), sea ice was almost at its maximum extent. Results presented here suggest that sea-ice areal expansion at this low-wind period switched from being a mix of dynamic and thermodynamic ice advance to being largely thermodynamically driven, enhanced by lower SSTs to the north of the ice edge in the region of the Ross, Amundsen and Bellingshausen seas in particular.

Certain questions regarding the 2013 sea-ice pattern remain unanswered:

What caused the relatively cold pools of SST offshore of the East Antarctic to Ross Sea sector? Were they formed by off-ice cold air advection, increased freshwater inputs and/or an oceanic circulation anomaly?

What caused the Ross Sea cold pool to spread to the east during the mid-advance period?

What part did freshening and cooling of the ocean surface play in enhanced sea-ice advance in the western Ross Sea (in particular)?

Did any change in precipitation patterns occur to affect upper-ocean stratification (stabilization) and salinity (freshening)?

Are the sea-ice seasonality patterns in 2013 somehow linked to an underlying shift in air and/or ocean circulation that will be more prevalent in future years, or a more random variation that is unlikely to become a trend? Are the 2012 and 2013 record maxima and high winter-season extents related?

Analysis of sea surface salinity maps derived from the Aquarius CAP L3 satellite dataset (results not shown) suggest a freshening of the surface just to the north of the Ross Sea in March 2013 (although this is a preliminary analysis and the data are relatively far from the ice edge). Past studies have shown that the Ross Sea has freshened over the last 50 years (1958-2008) (Jacobs and Giulivi, 2010) and that subsurface temperatures have changed (Goosse and others, 2009). Such results suggest that future analysis of currently deployed profiling floats in this region will be an invaluable addition to this current study. Similarly, an examination of precipitation, 
derived from the Australian Community Climate and Earth System Simulator (ACCESS) dataset, does not show any marked relationship to the freshening of the ocean surface in this region, or a role in the broad-scale sea-ice advance during 2013. Precipitation over the high latitudes of the Southern Hemisphere has variable impacts on sea ice (Maksym and Markus, 2008; Liu and Curry, 2010). Precipitation over data-sparse regions is difficult to monitor, and more work needs to go into observing and analysing this important variable. Other possible causes of regional ocean surface freshening that may affect sea ice are ice-shelf melt and/or outflow of continental sub-ice-sheet lake water (Flament and others, 2013; Livingstone and others, 2013; McMillan and others, 2013). Clearly, this potential linkage merits further in-depth and cross-disciplinary investigation.

\section{ADDITIONAL INFORMATION}

The method used to calculate various values of sea-ice measurements should be explained, especially given that the record monthly average sea-ice extent is larger than the daily record (see Table 1). Daily values of sea-ice extent are obtained by calculating the area that is bounded by the $15 \%$ ice concentration isoline. Daily sea-ice area is the sea-ice extent multiplied by its concentration. Monthly averaged values of extent and area are derived from daily maps of concentration such that there is a $50 \%$ chance of ice (concentration $\geq 15 \%$ ) being present in that month within a particular pixel.

\section{ACKNOWLEDGEMENTS}

We thank Melanie Webb, Andrew Watkins and anonymous reviewers for providing comments and advice on earlier drafts of this paper. Sea-ice data were obtained from the NASA Earth Observing System Distributed Active Archive Center (DAAC) at the US National Snow and Ice Data Center, University of Colorado, Boulder, CO, USA (http:// www.nsidc.org). Mean sea-level and precipitation data were from the ACCESS dataset provided by the Australian Bureau of Meteorology, Hobart, Australia. Sea surface salinity data were obtained from http://podaac.jpl.nasa.gov, maintained by the NASA Jet Propulsion Laboratory (JPL) Physical Oceanography DAAC, Pasadena, CA, USA. The SST data were obtained from Reynolds and Smith OI.v2, which are available from late 1981 onwards (Reynolds and others, 2002; Smith and others, 2008). The monthly mean SST climatologies were obtained from the US National Oceanic and Atmospheric Administration at http://origin.cpc.ncep. noaa.gov/products/people/yxue/sstclim/. SAM data are those derived by Marshall (2003) and acquired from the British Antarctic Survey: http://www.nerc-bas.ac.uk/icd/gjma/sam. html. This work was supported by the Australian Government's Cooperative Research Centre (CRC) programme through the Antarctic Climate and Ecosystems CRC under Australian Antarctic Science project 4116 (R.M., P.R., J.L.), US NASA grant NNX11AF44G (T.S.) and US National Science Foundation grant ANT-0823101 (S.S.).

\section{REFERENCES}

Bintanja R, Van Oldenborgh GJ, Drijfhout SS, Wouters B and Katsman CA (2013) Important role for ocean warming and increased ice-shelf melt in Antarctic sea-ice expansion. Nature Geosci., 6(5), 376-379 (doi: 10.1038/ngeo1767)
Cavalieri D, Parkinson C, Gloersen P and Zwally HJ (1996) Sea ice concentrations from Nimbus-7 SMMR and DMSP SSM/I-SSMIS passive microwave data, (1981-2013). National Snow and Ice Data Center, Boulder, CO http://nsidc.org/data/nsidc-0051.html

Coggins JHJ, McDonald AJ and Jolly B (2014) Synoptic climatology of the Ross Ice Shelf and Ross Sea region of Antarctica: k-means clustering and validation. Int. J. Climatol., 34(7), 2330-2348 (doi: 10.1002/joc.3842)

Cohen L, Dean S and Renwick J (2013) Synoptic weather types for the Ross Sea region, Antarctica. J. Climate, 26(2), 636-649 (doi: 10.1175/JCLI-D-11-00690.1)

Comiso JC (2010) Variability and trends of the global sea ice cover. In Thomas DN and Dieckmann GS eds. Sea ice. WileyBlackwell, Oxford, 205-246

Comiso JC and Nishio F (2008) Trends in the sea ice cover using enhanced and compatible AMSR-E, SSM/I, and SMMR data. J. Geophys. Res., 113(C2), C02S07 (doi: 10.1029/ 2007JC004257)

Flament T, Berthier E and Rémy F (2013) Cascading water underneath Wilkes Land, East Antarctic Ice Sheet, observed using altimetry and digital elevation models. Cryos. Discuss., 7(2), 841-871 (doi: 10.5194/tcd-7-841-2013)

Fogt R and Scambos TA (2013) Antarctica. In Blunden J and Arndt DS eds. State of the climate in 2012. (Special supplement to the Bulletin of the American Meteorological Society, 94(8)), S133-S146

Goosse H, Lefebvre W, De Montety A, Crespin E and Orsi AH (2009) Consistent past half-century trends in the atmosphere, the sea ice and the ocean at high southern latitudes. Climate Dyn., 33(7-8), 999-1016 (doi: 10.1007/s00382-008-0500-9)

Harangozo SA (2006) Atmospheric circulation impacts on winter maximum sea ice extent in the west Antarctic Peninsula region (1979-2001). Geophys. Res. Lett., 33(2), L02502 (doi: 10.1029/ 2005GL024978)

Hellmer H, Kauker F, Timmermann R, Determann J and Rae J (2012) Twenty-first-century warming of a large Antarctic iceshelf cavity by a redirected coastal current. Nature, 485(7397), 225-228 (doi: 10.1038/nature11064)

Holland PR and Kwok R (2012) Wind-driven trends in Antarctic sea-ice drift. Nature Geosci., 5(12), 872-875 (doi: 10.1038/ ngeo1627)

Hosking JS, Orr A, Marshall GJ, Turner J and Phillips T (2013) The influence of the Amundsen-Bellingshausen Seas low on the climate of West Antarctica and its representation in coupled climate model simulations. J. Climate, 26(17), 6633-6648 (doi: 10.1175//CLI-D-12-00813.1)

Jacobs SS and Giulivi C (2010) Large multidecadal salinity trends near the Pacific-Antarctic continental margin. J. Climate, 223(17), 4508-4524 (doi: 10.1175/2010JCLI3284.1)

Kimura N and Wakatsuchi M (2011) Large-scale processes governing the seasonal variability of the Antarctic sea ice. Tellus A, 63(4), 828-840 (doi: 10.1111/j.1600-0870.2011.00526.x)

Li X, Holland DM, Gerber EP and Yoo C (2014) Impacts of the north and tropical Atlantic Ocean on the Antarctic Peninsula and sea ice. Nature, 505(7484), 538-542 (doi: 10.1038/nature12945)

Liu J and Curry JA (2010) Accelerated warming of the Southern Ocean and its impacts on the hydrological cycle and sea ice. Proc. Natl Acad. Sci. USA (PNAS), 107(34), 14 987-14 992 (doi: 10.1073/pnas.1003336107)

Liu J, Curry JA and Martinson DG (2004) Interpretation of recent Antarctic sea ice variability. Geophys. Res. Lett., 31(2), L02205 (doi: 10.1029/2003GL018732)

Livingstone SJ, Clark CD, Woodward J and Kingslake J (2013) Potential subglacial lake locations and meltwater drainage pathways beneath the Antarctic and Greenland ice sheets. Cryosphere, 7(6), 1721-1740 (doi: 10.5194/tc-7-1721-2013)

Maksym T and Markus T (2008) Antarctic sea ice thickness and snow-to-ice conversion from atmospheric reanalysis and passive microwave snow depth. J. Geophys. Res., 113(C2), C02S12 (doi: 10.1029/2006JC004085) 
Marshall GJ (2003) Trends in the Southern Annular Mode from observations and reanalyses. J. Climate, 16(24), 4134-4143 (doi: 10.1175/1520-0442(2003)016<4134:TITSAM >2.0.CO;2)

Massom RA and Stammerjohn SE (2010) Antarctic sea ice change and variability - physical and ecological implications. Polar Sci., 4(2), 149-186 (doi: 10.1016/j.polar.2010.05.001)

Massom RA, Stammerjohn SE, Barreira S, Lieser J and Scambos T (2013a) [Antarctic] Sea ice extent and concentration. In Blunden $J$ and Arndt DS eds. State of the climate in 2012. (Special supplement to the Bulletin of the American Meteorological Society, 94(8)), S141-S142

Massom R, Reid P, Stammerjohn SE, Raymond B, Fraser A and Ushio $S$ (2013b) Change and variability in East Antarctic sea ice seasonality, 1979/80-2009/10. PLoS ONE, 8(5), (doi: 10.1371/ journal.pone.0064756)

McMillan M, Corr H, Shepherd A, Ridout A, Laxon S and Cullen R (2013) Three-dimensional mapping by CryoSat-2 of subglacial lake volume changes. Geophys. Res. Lett., 40(16), 4321-4327 (doi: 10.1002/grl.50689)

Nihashi S and Ohshima KI (2001) Relationship between ice decay and solar heating through open water in the Antarctic sea ice zone. J. Geophys. Res., 106(C8), 16 767-16 782 (doi: 10.1029/ 2000JC000399)

Parkinson CL and Cavalieri DJ (2012) Antarctic sea ice variability and trends, 1979-2010. Cryosphere, 6(4), 871-880 (doi: 10.5194/tc-6-871-2012)

Pritchard HD, Ligtenberg SRM, Fricker HA, Vaughan DG, Van den Broeke MR and Padman L (2012) Antarctic ice-sheet loss driven by basal melting of ice shelves. Nature, 484(7395), 502-505 (doi: 10.1038/nature10968)

Reid PA, Tully MB, Klekociuk AR, Krummel PB and Rhodes SK (2013) Seasonal climate summary Southern Hemisphere (spring 2012): warmer and drier across much of Australia, along with a new Southern Hemisphere sea ice extent record. Austral. Meterol. Oceanogr. J., 63(3), 427-442

Reynolds RW, Rayner NA, Smith TM, Stokes DC and Wang W (2002) An improved in situ and satellite SST analysis for climate. J. Climate, 15(13), 1609-1625 (doi: 10.1175/1520-0442(2002) 015<1609:AlISAS>2.0.CO;2)

Rignot E, Jacobs S, Mouginot J and Scheuchl B (2013) Ice shelf melting around Antarctica. Science, 341(6143), 266-270 (doi: 10.1126/science.1235798)

Schneider DP, Deser C and Okumura Y (2012) An assessment and interpretation of the observed warming of West Antarctica in the austral spring. Climate Dyn., 38(1-2), 323-347 (doi: 10.1007/ s00382-010-0985-x)

Sigmond M and Fyfe JC (2010) Has the ozone hole contributed to increased Antarctic sea ice extent? Geophys. Res. Lett., 37(18), L18502 (doi: 10.1029/2010GL044301)

Sigmond M and Fyfe JC (2014) The Antarctic sea ice response to the ozone hole in climate models. J. Climate, 27(3), 1336-1342 (doi: 10.1175/JCLI-D-13-00590.1)

Simpkins GR, Ciasto LM, Thompson DWJ and England MH (2012) Seasonal relationships between large-scale climate variability and Antarctic sea ice concentration. J. Climate, 25(16), 5451-5469 (doi: 10.1175/JCLI-D-11-00367.1)
Smith TM, Reynolds RW, Peterson TC and Lawrimore J (2008) Improvements to NOAA's historical merged land-ocean surface temperature analysis (1880-2006). J. Climate, 21(10), 2283-2296 (doi: 10.1175/2007JCLI2100.1)

Stammerjohn SE, Martinson DG, Smith RC, Yuan X and Rind D (2008) Trends in Antarctic annual sea ice retreat and advance and their relation to El Niño-Southern Oscillation and Southern Annular Mode variability. J. Geophys. Res., 113(C3), C03S90 (doi: 10.1029/2007JC004269)

Stammerjohn S, Massom R, Rind D and Martinson D (2012) Regions of rapid sea ice change: an inter-hemispheric seasonal comparison. Geophys. Res. Lett., 39(6), L06501 (doi: 10.1029/ 2012GL050874)

Stroeve JC, Serreze MC, Holland MM, Kay JE, Malanik J and Barrett AP (2012) The Arctic's rapidly shrinking sea ice cover: a research synthesis. Climatic Change, 110(3-4), 1005-1027 (doi: 10.1007/s10584-011-0101-1)

Tamura T, Williams GD, Fraser AD and Ohshima KI (2012) Potential regime shift in decreased sea ice production after the Mertz Glacier calving. Nature Commun., 3, 826 (doi: 10.1038/ ncomms1820)

Turner J and 8 others (2009) Non-annular atmospheric circulation change induced by stratospheric ozone depletion and its role in the recent increase of Antarctic sea ice extent. Geophys. Res. Lett., 36(8), L08502 (doi: 10.1029/ 2009GL037524)

Turner J, Phillips T, Hosking JS, Marshall GJ and Orr A (2013a) The Amundsen Sea low. Int. J. Climatol., 33(7), 1818-1829 (doi: 10.1002/joc.3558)

Turner J, Hosking JS, Phillips T and Marshall GJ (2013b) Temporal and spatial evolution of the Antarctic sea ice prior to the September 2012 record maximum extent. Geophys. Res. Lett., 40(22), 5894-5898 (doi: 10.1002/2013GL058371)

Turney C (2014) This was no Antarctic pleasure cruise. Nature, 505 (7482), 133 (doi: 10.1038/505133a)

Watkins AB and Simmonds I (1999) A late spring surge in the open water of the Antarctic sea ice pack. Geophys. Res. Lett., 26(10), 1481-1484 (doi: 10.1029/1999GL900292)

Watkins AB and Simmonds I (2000) Current trends in Antarctic sea ice: the 1990s impact on a short climatology. J. Climate, 13(24), 4441-4451 (doi: 10.1175/1520-0442(2000)013<4441:CTIASI> 2.0.CO;2)

Wovrosh AL, Barreira S, Fogt RL and Scambos TA (2013) [Antarctic] Circulation, in 'State of the Climate in 2012'. Bull. Am. Meteor. Soc., 94(8), S133-S135

Yuan X and Li C (2008) Climate modes in southern high latitudes and their impacts on Antarctic sea ice. J. Geophys. Res., 113 (C6), C06S91 (doi: 10.1029/2006JC004067)

Zhang Z (2014) Modeling the impact of wind intensification on Antarctic sea ice volume. J. Climate, 27(1), 202-214 (doi: 10.1175/JCLI-D-12-00139.1)

Zwally HJ, Comiso JC, Parkinson CL, Campbell WJ, Carsey FD and Gloersen P (1983) Antarctic sea ice, 1973-1976: satellite passive-microwave observations. (NASA Special Publication SP-459) National Aeronautics and Space Administration, Washington, DC 